\title{
THE ROLES OF PERCEIVED RISKS AND PRICE ON THE PURCHASE INTENTION OF CHINA- MADE HOME APPLIANCES AMONG CAREER WOMEN IN MALAYSIA
}

\author{
NOOR AZMI HASHIM \\ ZOLKAFLI HUSIN \\ ISMAIL LEBAI OTHMAN \\ ALI YUSOB MD ZAIN \\ School of Business Management, \\ UUM College of Business \\ Universiti Utara Malaysia
}

\begin{abstract}
The purpose of this research paper is to report on the purchase intention of China-made home appliances among career women in Malaysia. The purchase intention is hypothesised to be influenced by the price and preference of today's career women who are indifferent to the product's country of origin and brand. Data were collected by random sampling from 430 career women in selected states in Malaysia in 2016 and were used to test the hypotheses. Survey questionnaires were used to collect the data by utilising a self-administrated method. The relationships between price, perceived risks, attitude toward brand, and purchase intention were tested in this study. The results showed that price is the main factor being considered by the career women in Malaysia when they decide to purchase China-made home appliances. This study implied that marketers need to capitalise on pricing strategy in order to market their home appliances among career women.
\end{abstract}

Keywords: China-made, Purchase intention, Perceived risk, Attitude towards brand, Malaysia.

Received: 03/04/2017 Revise: 18/06/2017 Accepted:05/07/2017 Publish: 27/7/2017

\section{Introduction}

Chinese brand export products, commonly referred to as "Made in China" products are available around the world, including Malaysia. The demand for these imported products is on the rise, in particular 
for the home appliances of electrical/mechanical machines which accomplish some household functions (Kavita \& Narendra, 2013), such as cooking or cleaning. The home appliances can be classified into (i) major appliances, for example, air conditioners, refrigerators, and washing machines, (ii) small appliances, for example, fans, juicers, and coffee makers, and (iii) consumer electronics, for example, TVs, DVD players, clocks, and telephones.

Previously, Chinen and Sun (2011) mentioned that China's image as a country of origin for a product is viewed as being negative. China is known to produce low quality electronic products at an affordable price, thus, the country has the image and reputation of being the low-cost producer in the world. As the world market changes over time, product quality and brand-building will emerge and grow. Chinese brands gradually start to obtain more recognition, having similar reputation to products produced in Japan and Korea. It appears that Chinese brands have transformed into global brands.

In recent years, China has developed a better image perception for each of their product brands (Ho \& Svein, 2012). The emergence of these quality brands is expected to erase the previous negative stereotype and perception of products that consumers have in their mind. Today, electrical appliances such as air conditioners, washing machines, refrigerators, and TVs originate from China and have already gained world class reputation. In this research, the focus was on China's brand home appliances directly related to consumers' daily chores, by enhancing understanding of consumer purchase intentions toward Chinese brands.

\section{Purchase Intention}

\section{Literature Review}

The studies on purchase intention has been widely researched (Gurjeet \& Tahira, 2015; Justin, Ryan, Tamsin, \& Melissa, 2013). Products marketed domestically or internationally can successfully apply this concept. Previous studies showed that purchase intention leads to a variety of determinants regarding purchase intention (Jeffrey \& Ann, 2016; Yujie, 2008). Normally, purchase intention represents how consumers think and what they will buy (Blackwell, Miniard, \& Engel, 2001). Warshaw and Davis (1985) defined purchase intention as "the degree to which a person has formulated conscious plans to perform or not to perform some specified future behaviour". Studies indicated that positive belief is related to consumers with a high level of purchase intention (Ho \& Svein, 2012). Thus, in general, it can be 
said that intention to buy is measured in terms of the consumers' likelihood to act toward a particular object (Jae-Eun, Leslie, Yingiiao, \& Jing, 2012).

\section{Relationship between Perceived Risk and Purchase Intention}

Research on different risk reduction strategies were conducted on how consumers minimise risk (Schiffman \& Kanuk, 2015). In particular, warranty has been revealed by Erevelles (1993) as a useful strategy in minimising consumer's purchase risk. This means that understanding how risks are perceived by different segments and the importance of learning how to reduce perceived risk are relevant. It is also valuable to know what actions have to be taken to reduce risk for different types of customers (Justin, Ryan, Tamsin, \& Melissa, 2013). After all, consumer willingness to buy increases when the perceived risk of purchasing decreases (Matthew, James, Gui, Rongwei, \& TingHsiang, 2013). For example, women are more willing to take risks if they feel that there are many others who are doing the same, even though they knew that the outcomes will be negative (Ning, Andrew, \& Nigel, 2013).

The sense of risk reduction plays a role in the willingness to buy as the idea of having a shared experience (Garbarini \& Strahilevitz, 2004). Studies by Mitchell, Davies, Moutinho, and Vassos (1999) found that the purchase intention is negatively associated with perceived risk of the product. However, Ning, Andrew, and Nigel (2013) found that consumer purchase intention has insignificant effect on perceived risk. According to Chau (2013), perceived risks should be observed as a combination of perception of the likelihood that something will go wrong and the seriousness of the consequences if it does. Meanwhile, Murphy and Enis (1986) defined risk as "the nature and amount of uncertainty perceived by consumers in complementing a particular purchase decision".

Previous studies confirmed that consumers perceive various types of risks in making purchase decisions. The types of risks defined by Murphy and Enis (1986) include (i) financial risks (losing money when the product does not meet expectations), (ii) psychological risks (negative effect on the ego when choosing a wrong product), (iii) physical risks (risk of physically harming oneself when using a product), (iv) social risks (change in social status due to the choice of products), and (v) functional risks (risk of product malfunction). 
Schiffman and Kanuk (2015) revealed that consumers would pay more attention to actions that will reduce risks in addition to the knowledge acquired in understanding such risks. Previous research examining risk perceptions highlighted that there is negative correlation between risk perception and willingness to buy (Shimp \& Bearden, 1982; White \& Truly, 1989). Well-known brand and performance are closely related, thus buying such brand will guarantee quality and reduce risk. For Ede and Panigrahi (2000), a well known brand can also provide social visibility. One point to ponder is that consumers are constantly making decisions in relation to what and where to buy the product. Thus, the outcomes of such decisions are often uncertain where the consumers perceive some forms of risk in deciding to purchase.

Previous research provided evidence that purchase intention is negatively related to perceived risk (Mitchell, Davies, Moutinho, \& Vassos, 1999; Justin, Ryan, Tamsin, \& Melissa (2013). However, Matthew et al. (2013) contested that perceived risk has no significant effects on purchase intention of customers with regard to home appliances. This inconsistency leads to the hypothesis in this study relating to perceived risk and purchase intention.

\section{Relationship between Price and Purchase Intention}

Evaluation of a product by consumers as well as their choice of a product can be affected by price as an extrinsic cue. Consumers' purchase decisions are influenced by price, but normally it does not directly associate with product performance (Keller, 2003). Whether or not a particular brand is considered by consumers, the perception of a brand's price helps to determine their preference (Dyson, Farr, \& Hollis, 1996). In addition, price is an important brand association because consumer's belief in price and value of a brand are associated with the product (Cristina, \& Jean-Pierre, 2016). Consumers' motives are positively related to perceived price (Rong-Da, 2016) and these motives stimulate their responses and encourage them to visit the store (Justin, Ryan, Tamsin, \& Melissa, 2013). Furthermore, there is evidence indicating that consumers are most attracted to low cost products (Hernan, Eman, \& Rosa, 2012).

For certain consumers, for example the American consumers, nationalism plays a dominant role in influencing purchasing behaviour when price and quality are constant. They are likely to purchase local products without sacrificing the perceived quality (Justin et al., 2013). A study by Faruk (2015) revealed that product 
cues (price and quality) may have a stronger effect on US consumer product evaluation than the country of origin. Findings by Chao (1993) indicated that consumers perceive that higher price represents better quality and they are willing to pay more. This shows that product cues are good predictors of purchase intention.

To this end, it is important to highlight the finding by Rong-Da (2016) which showed that price has a positive relationship with consumers' motives. The motive drives their behaviour together and stimulates the responses to purchase (Justin et al., 2013). However, it is also important to note that low price products are more attractive to a different segment of consumers. This is because people are becoming more price conscious, thus, low price products may become their target. The contradicting facts lead to the crucial need to examine the effect of price and perceived risks on the purchase intention of products made in China.

\section{Attitude toward Brand as the Mediator}

Attitude is best described as the psychological tendency of a person to respond and behave in a consistent manner to a stimulus (Page \& Luding, 2003). Previous research showed that consumer behaviour is predicted by knowing the attitudes at that moment when the behaviour takes place (Ajzen, 2000; Ajzen \& Fishbein, 2000; Page \& Yuding, 2003). Foxall and Pallister (1998) classified attitude into two aspects, which are the rational and the emotional aspects, suggesting that the rational aspect is more dominant in the purchase decision of financial products. Within this article, the attitude toward a brand is defined as the predisposition to respond consistently in a favourable or unfavourable manner to a particular brand, rationally.

Before discussing on the attitude toward brand, the importance of brand needs to be highlighted. Brand is an element that requires urgent attention to an organisation (Kotler \& Armstrong, 2015). Although, some view branding as just a logo or package, Kotler and Armstrong (2015) suggested that it should be viewed as a combination of all physical and emotional characteristics at all points of contact. Brand is closely related to perceived quality and also perceived risks and thus reflected in the pricing of a product (Keller, 2003). For example, a BMW car is associated with being a high quality vehicle with the low physical, psychological, and functional risks. Therefore, it is sold at a higher price compared to most other brands. However, for the PROTON car, it is more price sensitive. Consumers who have obtained emotional satisfaction from a brand will be less price sensitive. This 
reflects that positive attitude toward brand has favourable effect, and when consumers have such positive attitude, the brand market share will increase (Baldlinger, 1996).

Previous studies recommended that marketers should focus on changing consumer attitudes before influencing their purchase intention decisions (Berger, Ratchford, \& Haines, 1994; Huang, Lee, $\&$ Ho, 2004). Purchase intention is a type of judgment that emerges when a customer thinks of buying a specific brand. Consumers need to make an explicit overall evaluation of all brands before forming a purchase intention. Prior research had predominantly used purchase intention as a proxy for actual choice, as a person's intention is often an accurate predictor of their behaviour (Ajzen, 2000). Previous research also showed that attitude toward brand has significantly impacted the intention to buy that brand (Brown \& Stayman, 1992; Homer 1990).

Huang et al. (2004), whilst investigating the relationship between attitudes toward gray market and purchase intention, reported that attitude toward the gray market is significantly and positively related to purchase intention. Choo, Chung, and Pysarchik (2004) in their study on antecedents of new food product purchasing behaviour in India found that attitude toward brand has a positive effect on intention to buy. In addition, Teng, Laroche, and Zhu (2007) also found that consumers' attitudes toward a brand positively influence their intentions to purchase that particular brand. Thus, in summary, it appears that there is a relationship between attitude toward brand and purchase intention.

\section{Methodology}

Cross-sectional data were collected by using a questionnaire adapted from previous studies, for example, Agrawal and Teas (2002), Field (2000), and Burton, Lichtenstein, Netemeyer, and Garretson (1998). To ensure the anonymity of data, the questionnaires were selfadministered. The population for this study comprised career women in the selected states of Perlis, Kedah, Penang, Kuala Lumpur, Selangor, and Negeri Sembilan. In this study, all employed or working females were considered as career women. Career women were selected because (i) they are mature, (ii) they have own income as employees, (iii) they have the experience and knowledge about home appliances, and (iv) most of them have already purchased the China-made home appliances. 
In determining the required sample size of the identified population with the desired accuracy, the researcher used the Krejcie and Morgan (1970) table cited in Sekaran (2013). The minimum required sample size for this study was calculated to be 399 at the $95 \%$ confidence level. In fact, according to Sekaran (2013) and Field (2000), a sample size of at least 300 will usually provide reliable results in factor analysis. Furthermore, responses between 300 and 500 is recommended and accepted as the critical sample size for multiple regressions (Hair, Black, Babin, Anderson, and Tatham (2013). Expecting a 40\% response rate, a total of 900 questionnaires was distributed. Each questionnaire was accompanied by a cover letter to explain the purposes of the study. Respondents were given instructions on how to answer the questionnaire and they were also given the assurance on the confidentiality of the data gathered. For the measurement of price, seven items were taken from Agrawal and Teas (2002), five items for perceived risks (Field, 2000), six items for attitude toward brand (Burton's et al., 1998), and four items for intention to purchase (Agrawal \& Teas 2002).

The conceptual framework consisted of three sets of variables: (a) independent variables, (b) mediating variable, and (c) dependent variable. The foundation of this construct was based on several previous theoretical and empirical studies (Agrawal \& Teas, 2002; Field, 2000). Figure 1 is the graphical representation of the theoretical framework. The effect of price and perceived risk was examined in direct and indirection methods on intention. In indirect relation attitude established the relationship between price, perceived risk, and intention.

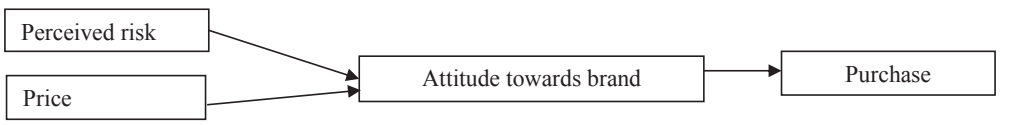

Figure 1. Theoretical framework

The following hypotheses were tested in the study and the results are presented in the next section.

i. There is significant contribution of product cues (price and perceived risks) to purchase intention.

ii. There is significant contribution of product cues (price and perceived risks) to attitude toward brand. 
iii. There is significant contribution of attitude toward the brand to purchase intention.

iv. There is significant mediating effect of attitude toward brand on the effects of product cues (price and perceived risks) on purchase intention.

\section{Results and Analysis}

A total of 465 questionnaires was returned from 900 questionnaires that were distributed. The response rate was 51.66\%. From the 465 questionnaires, a total of 35 questionnaires was rejected due to several reasons, namely incomplete answers (35). Therefore, only $430(47.77 \%)$ questionnaires were coded and analysed. Respondents were asked questions pertaining to age, gender, ethnicity, marital status, occupation, income, ownership, and knowledge. The majority of respondents were in the 25-35 age group (69.8\%), followed by the 36-45 age group (23.3\%). Next was the less than 25 age group $(4.7 \%)$, followed by the $46-55$ age group $(2.3 \%)$. From the total of 430 respondents, all were women $(100 \%)$. In terms of ethnic group, the majority were Malay (70.9\%), followed by Indian (14\%), Chinese $(12.8 \%)$, and other races (2.3\%). In terms of marital status, 310 or $72.3 \%$ were married, $115(26.7 \%)$ were single, and $5(1.2 \%)$ were divorced or separated.

A total of $260(60.5 \%)$ respondents was employed in the private sector, followed by the public sector ( 165 or $38.4 \%)$, and own business (5 or $1.2 \%$ ). On income, $39.5 \%$ of respondents earned more than RM 4001 monthly, followed by those earning between RM 3001 and RM $4000(25.6 \%)$. Meanwhile, $23.3 \%$ of the respondents earned between RM 2001 and RM 3000. A small percentage of $11.6 \%$ had a monthly income between RM 1001 and RM 2000. Table 1 represents the profile of respondents.

Table 1

Profile of Respondents

\begin{tabular}{llcc}
\hline Demographics & \multicolumn{1}{c}{ Category } & Frequency & $\%$ \\
\hline Age & $<25$ & 20 & 4.7 \\
& $25-35$ & 300 & 69.8 \\
& $36-45$ & 100 & 23.3 \\
\hline
\end{tabular}


IJMS 24 (1), 169-185 (2017)

\begin{tabular}{llrr}
\hline Demographics & \multicolumn{1}{c}{ Category } & Frequency & $\%$ \\
\hline \multirow{3}{*}{ Gender } & $46-55$ & 10 & 2.3 \\
Ethnic group & Female & 430 & 100.0 \\
& Malay & 305 & 70.9 \\
& Chinese & 55 & 12.8 \\
& Indian & 60 & 14.0 \\
& Others & 10 & 2.3 \\
Marital & Single & 115 & 26.7 \\
& Married & 310 & 72.3 \\
& Divorced or Separated & 5 & 1.2 \\
& Public sector & 165 & 38.4 \\
& Private sector & 260 & 60.5 \\
& Business & 5 & 1.2 \\
Monthly income & Less than RM 1000 & 0 & 0 \\
& RM 1001 - RM 2000 & 50 & 11.6 \\
& RM 2001 - RM 3000 & 100 & 23.3 \\
& RM 3001 - RM 4000 & 110 & 25.6 \\
& More than RM 4001 & 170 & 39.5 \\
\hline
\end{tabular}

Table 2

Correlation

\begin{tabular}{lcccc}
\hline & Price & Perceived Risk & Attitude & Intention \\
\hline Price & 1 & & & \\
Perceived & $-.550^{* *}$ & 1 & & \\
Risk & .017 & .016 & 1 & \\
Attitude & $.375^{* *}$ & $-.567^{* *}$ & $.126^{*}$ & 1 \\
Intention &
\end{tabular}

**. Correlation is significant at the 0.01 level (2-tailed).

*. Correlation is significant at the 0.05 level (2-tailed).

The reliability for each measure was examined by computing its Cronbach's alpha value. The reliability of a measure indicates the stability and consistency of the instrument in measuring a concept 
and helps to assess the goodness of a measure (Sekaran, 2013). Sekaran (2013) suggested that the minimum acceptable reliability value to be 0.60 . The Cronbach's alpha for price was 0.82 , perceived risk at 0.80 , attitude toward brand was 0.79 , and for purchase intention it was 0.87 . The Pearson product-moment correlation coefficients $(r)$ were computed to examine the correlations and directions among the study variables to determine the interdependency of the variables under study. Table 2 indicates the correlation results.

To test the hypotheses, multiple regression analysis was carried out to determine the relationship of product cues price, perceived risk, and purchase intention. Table 3 demonstrates the results of the regression analysis.

Table 3

Multiple Regression Analysis

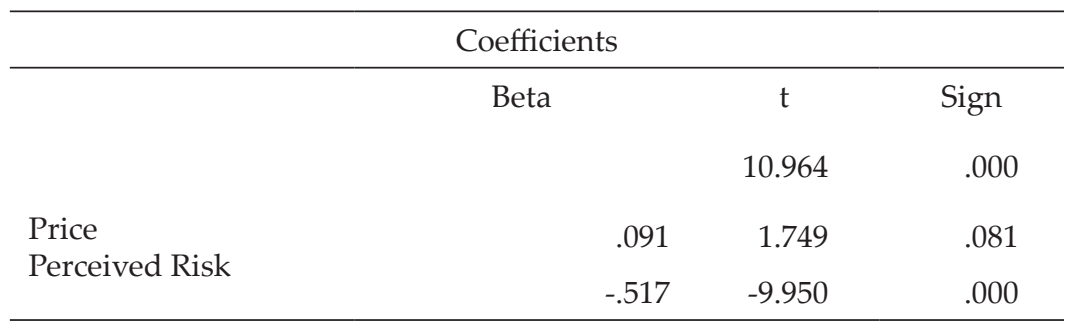

a. Dependent Variable: Intention

The results of direct effect indicated that price did not directly effect on making consumer intention to purchase a brand product, whereas perceived risk has a significantly negative effect. The negative effect revealed that when the risk is higher the purchase intention will be lower and vice versa. It was found that attitude toward brand explains $8.3 \%\left(R^{2}=.08\right)$ of the variance in purchase intention. The dimension of attitude toward brand $\left(\Omega=.35^{* * *}, \mathrm{p}<.01\right)$ is positively and significantly associated with purchase intention.

To test the mediating effect, Baron and Kenny's (1986) approach was implemented. Multiple regression analysis was carried out to test the mediating effect of attitude toward brand on the relationship of price, perceived risk, and purchase intention. Table 4 represents the mediation results. 
IJMS 24 (1), 169-185 (2017)

Table 4

Mediation results

\begin{tabular}{lccll}
\hline & Coefficients $^{\mathrm{a}}$ & & \multicolumn{1}{l}{ Decision } \\
\hline \multirow{2}{*}{ Price } & Beta & $\mathrm{t}$ & $\mathrm{p}$ & \\
& .091 & 1.749 & .010 & supported \\
Perceived Risk & -.517 & -9.950 & .000 & Supported \\
Price & .086 & 1.672 & .050 & Partial Mediation \\
Perceived Risk & -.522 & -10.159 & .000 & Partial mediation \\
Attitude & .133 & 3.092 & .002 & \\
& & & & \\
\hline
\end{tabular}

a. Dependent Variable: Intention

\section{Contributions of the Study}

The results of this study provide several theoretical and practical implications. The study provides empirical support for the relationships between the variables included in the theoretical framework. The linkages between consumers' product cues (price and perceived risks), attitude towards brand, and purchase intention were found to be supported by the data. The knowledge on the importance of product cues as an antecedent to purchase intention, as suggested by previous research, has been further advanced by the findings of this study.

This study also provides evidence on the importance of attitude towards brand as an intervening variable between product cues and purchase intentions. The evidence for the existence of both the direct and indirect effects (mediated by attitude towards brand) of product cues on purchase intentions was also clearly indicated in this study. This contributes to our understanding of the role of attitudes towards brand in the formation of purchase intentions among consumers in the Malaysian context.

The findings from this study provide several insights for the manufacturers, assemblers and distributors of China's brands in Malaysia. Results from this study could be utilized by marketing managers to devise strategies to enhance the consumers' purchase intentions. Purchase intention was found to be having a significant positive relationship with one aspect of the product cues: price. 
Purchase intentions were also found to be indirectly affected by both the product cues included in this study, price and perceived risks, through attitude towards brand. The results of the study have also indicated that the purchase intention was directly affected by the attitude towards brand, implying that positive attitude towards brand would likely lead to a positive behavioural intention. These results could serve to guide marketers of China's brand home appliances to increase sales by leveraging on pricing strategies, and by promoting positive attutude towards their brands. Positive attitudes towards brand could be enhanced by promoting efforts to satisfy consumers' needs and preferences, and consequently would improve purchase intentions. This could be done through competitive pricing strategies and reducing perceived risks associated with the products.

\section{Limitations and Suggestions for Future Research}

Several limitations were identified and they are highlighted here so that readers can have a better understanding of the findings. First, the conclusion is based on the results obtained from the analysis only on the relationship between product cues (price and perceived risks), attitude towards brand and purchase intention.

Firstly, the focus of this study is the career women. The research needs to cover all women, not only career women, to the overall purchase intention of the China products. Secondly, the proportion of the ethnic group is not as the percentage given by the statistics, for example, there is more Chinese than Indian in Malaysia but the respondents consist $12.8 \%$ Chinese and $14.0 \%$ Indian. This may make the generalization less accurate. Thirdly, it is about the type of products under study, the home appliances. The coverage can be broaden to cover issues such as on the brands of home appliances available in Malaysia.

Finally, it is suggested that future research include both high and low involvement products. Thus, the more specific conclusion can be made, for example, in relation to product category. If a replication study to be performed, it is suggested to include different samples so that the stability of the model in predicting purchase intention can be established, thus should considerably enhance the understanding of purchase intention.

\section{Conclusion}

The study was cross-sectional in nature and purposive sampling method wasutilized to selectindividual respondents comprising of career woman. 
Data were gathered from career woman in Perlis, Kedah, Selangor, Kuala Lumpur and Negeri Sembilan. A total of 900 questionnaires were distributed and 465 (51.66 \%) were returned. However, only 430 $(47.77 \%)$ were usable, coded and analyzed. The internal consistency of the measures was tested by computing the Cronbach's alpha. Finally, the hypotheses were analyzed using hierarchical regression analysis. Purchase intention has received attention from many scholars in the past decade because purchase intention as verified by Fishbein and Ajzen (1967) belief-attitude-intention model, that buying intention could be an important index to predict consumer behaviour. In addition, later studies have confirmed that purchase intentions as the most accurate predictor of purchase behaviour (Narissara and Mario, (2012). In other word, firms' that could predict purchase intention will achieve a higher sales rate than their competitors. Also, the firm could understand the needs and wants in order to provide a superior value for customers.

This study found that price is significantly and positively related to purchase intention. The result implies that consumers' who have higher perceptions of price would be more likely to have higher levels of purchase intention. In relation to price, this study finding has showed that consumers perceived that the price of China's brand home appliances as an economical, reasonable and acceptable. The consumer also considered the price as a bargain which they perceived as a value and a good buy and they tend to have a higher purchase intention. The importance of price could be explained from the pricing strategy employed by the China's brand home appliance companies. Hence, the pricing needs to represent the product quality perception (Faruk, 2015). Thus, the need for pricing is perceived by this group of consumers' as an essential part of the product cues as well as for their purchase intention.

\section{Acknowledgement}

The funding of this research was provided by Ministry of Higher Education, Malaysia under the research acculturation grant scheme (RAGS) and Universiti Utara Malaysia.

\section{References}

Agrawal, S., \& Teas, R. K. (2002). Cross national applicability of a perceived quality model. The Journal of Product and Brand Management, 11(4/5), 213-237. 
Ajzen, I., \& Fishbein, M. (2000). The Prediction of Behaviour from Attitudinal and Normative Variables. Psychology Press, Philadelphia, PA.

Ajzen, I. (2000). Nature and operation of attitudes. Annual Review of Psychology, 52, 27-58.

Aqueveque, C. (2006). Extrinsic cues and Perceived risk: The influence of consumption situation. Journal of Consumer Marketing, 23(5), 237-247.

Baldlinger, A. L. (1996). Brand loyalty: The link between attitude and behaviour. Journal of Academy of Marketing Science, 16(1), 74-94.

Baron, R. M., \& Kenny, D. A. (1986). The moderator-mediator variable distinction in social psychological research: Conceptual, strategic and statistical considerations. Journal of Personality and Social Psychology, 51(6), 1173-1182.

Berger, I. E., Ratchford, B. T., \& Haines, G. H. (1994). Subjective product knowledge as a moderator of the relationship between attitudes and purchase intentions for a durable product. Journal of Economic Psychology, 15(2), 301-315.

Blackwell, R. D., Miniard, P. D., \& Engel, J. L. (2001). Consumer Behaviour. The Dryden Press: Orlando, FL.

Brown, S. P., \& Stayman, D. M. (1992). Antecedents and consequences of attitude towards the ad: A meta-analysis. Journal of Consumer Research, 19(2), 34-51.

Burton, S., Lichtenstein, D. R., Netemeyer, R. G., \& Garretson, J. A. (1998). A scale for measuring attitude toward private label products and an examination of its psychological and behavioural correlates. Journal of the Academy of Marketing Science, 26(4), 293-306

Chao, P. (1993). Partitioning country of origin effects: consumers' evaluations of a hybrid product. Journal of International Business Studies, 24(2), 291-306.

Chau, S. C. (2013). Perceived risk, usage frequency of mobile banking services Managing Service Quality, 23(5), 410-436.

Chinen, K., \& Sun, Y. (2011). Effects of Country-of-Origin on Buying Behaviour: A Study of the Attitudes of United States Consumers to Chinese-Brand Automobiles. International Journal of Management, 28(2), 553-563.

Choo, H., Chung, J. E., \& Pysarchik, D. T. (2004). Antecedents to new food product purchasing behaviour among innovator groups in India. European Journal of Marketing, 38(5/6), 608-625.

Cristina, C. P., \& Jean-Pierre, L. M. (2016). Food private label brands: The role of consumer trust on loyalty and purchase intention. British Food Journal, 118(3), 679-696. 
Dosen, D.O., Skare, V., \& Krupka, Z. (2006). Assessments of country of origin and brand cues in evaluating a Croation western and eastern food product. Journal of Business Research, 60, 130-136.

Dyson, P., Farr, A., \& Hollis, N. S. (1996). Understanding, measuring and using brand equity. Journal of Advertising Research, $36(6$ Nov/Dec), 9-21.

Ede, F. O., \& Panigrahi, B. (2000). African-American consumer attitudes toward domestic and foreign-made automobiles. Management Research Reviews, 23(5/6), 1-19.

Erevelles, S. (1993). The price-warranty contract and product attitudes. Journal of Business Research, 27, 171-81.

Faruk, A. K. (2015). The effects of price consciousness and sale proneness on purchase intention towards expiration datebased priced perishable foods. British Food Journal, 117(2),793804.

Field, J. R. B. (2000). An Empirical Investigation of Consumers' Perceptions and Purchase Intentions of Counterfeit Products: A Means-End Chain Analysis, (Unpublished PhD thesis). Mississipi State University.

Fishbein, M., \& Ajzen, I. (1975). Belief, attitude, intention and behaviour: An introduction to theory and research. Addison-Wesley, Reading, MA.

Fishbein, M., \& Ajzen, I. (1967). A behaviour theory approach to the relations between beliefs about an object and the attitude toward the object. In M. Fishbein (Ed.), Reading in attitude theory and measurement. New York: John Wiley \& Sons

Foxall, G., \& Pallister, J. (1998). Measuring purchase decision involvement for financial services. International Journal of Bank Marketing, 16(4/5), 180-195.

Garbarini, E., \& Strahilevitz, M. M. (2004). Gender differences in the perceived risk of buying online and the effects of receiving a site recommendation. Journal of Business Research, 57, 768-775.

Gurjeet, K., \& Tahira, K. Q. (2015). Factors obstructing intentions to trust and purchase products online. Asia Pacific Journal of Marketing and Logistics, 27(5),758-783.

Hair, J., Black, W., Babin, B., Anderson, R., \& Tatham, R. (2013). Multivariate data analysis ( $6^{\text {th }}$ ed.). Upper Saddle River, NJ: Prentice Hall.

Hernan, E. R., Eman, M. S. A., \& Rosa, E. R. (2012). Intention to purchase fake products in an Islamic country. Education, Business and Society: Contemporary Middle Eastern Issues, 5(1), 6-22. 
Ho, H. T., \& Svein, O. O. (2012). Certainty, risk and knowledge in the satisfaction-purchase intention relationship in a new product experiment. Asia Pacific Journal of Marketing and Logistics, 24(1), 78-101.

Homer, P. M. (1990). The mediating role of attitude towards the ad: Some additional evidence. Journal of Marketing Research, 27(2), 78-86.

Huang, J. H., Lee, C.Y., \& Ho, S. H. (2004). Consumer attitude toward gray market goods. International Marketing Review, 21(6), 598614.

Jae-Eun, C., Leslie, S., Yingjiao, X., \& Jing, R. (2012). Predicting Chinese consumers' purchase intentions for imported soybased dietary supplements. British Food Journal, 114(1), 43-161

Jeffrey, M. C., \& Ann, E. F. (2016). Reducing the intention-to-behaviour gap for locally produced foods purchasing; The role of store, trust, and price. International Journal of Retail $\mathcal{E}$ Distribution Management, 44(5), 508-523.

Justin, B., Ryan, F., Tamsin, G., \& Melissa, M. (2013). The influence of perceived product quality, relative price and risk on customer value and willingness to buy: A study of private label merchandise. Journal of Product \& Brand Management, 22(3), 218 -228 .

Kavita, S., \& Narendra, K. S. (2013). Consumer attitude towards brand extension: A comparative study of fast moving consumer goods, durable goods and services. Journal of Indian Business Research, 5(3), 177-197

Keller, K. L. (2003). Strategic Brand Management, Building, Measuring and Managing Brand Equity, ( $2^{\text {nd }}$ ed.). Upper Saddle River, New Jersey: Prentice-Hall, Pearson Education, Inc.

Kotler, P., \& Armstrong, G. (2001). Principles of marketing (9 $9^{\text {th }}$ ed.). Prentice Hall: New Jersey.

Matthew, T. L., James, L. B., Gui, C. S., Rongwei, C., \& Ting-Hsiang, T. (2013). Perceived benefits, perceived risk, and trust: influences on consumers' group buying behaviour. Asia Pacific Journal of Marketing and Logistics, 25(2), 225-248

Mitchell, V.W., Davies, F., Moutinho, L., \& Vassos, V. (1999). Using neural networks to understand service risk in the holiday product. Journal of Business Research, 46(2),167-180.

Murphy, P. E., \& Enis, B. M. (1986). Classifying products strategically. Journal of Marketing, 50, 24-42.

Narissara, P., \& Mario, J. M. (2012). The interaction effect of countryof-origin, brand equity and purchase involvement on consumer 
purchase intentions of clothing labels. Asia Pacific Journal of Marketing and Logistics, 24(1), 7-22.

Ning, L., Andrew, R., \& Nigel, C. (2013). Chinese consumers' purchasing: Impact of value and affect. Journal of Fashion Marketing and Management, 17(4), 486-508.

Page, C., \& Luding, Y. (2003). Bank managers' direct marketing dilemmas-customers' attitudes and purchase intention. International Journal of Bank Marketing, 21(3), 147-163.

Rong-Da, L. (2016). Predicting intentions to purchase organic food: the moderating effects of organic food prices. British Food Journal, 118(1), 183-199.

Schiffman, L. G., \& Kanuk, L.L. (2015). Consumer behaviour ( $7^{\text {th }}$ ed.). Prentice Hall.

Sekaran, U. (2013). Research methods for business: A skill-building approach ( $4^{\text {th }}$ ed.). John Wiley \& Sons, Inc. USA.

Shimp, T. A., \& Bearden, W. O. (1982). Warranty and other extrinsic cue effects on consumers' risk perceptions. Journal of Consumer Research, 9, 38-46.

Teng, L., Laroche, M., \& Zhu, H. (2007). The effect of multiple-ads and multiple-brands on consumer attitude and purchase behaviour. Journal of Consumer Marketing, 24(1), 27-35.

Washaw, P. R., \& Davis, F. D. (1985). Disentangling behavioural intention and behavioural expectation. Journal of Experimental Social Psychology, 21(3), 213-228.

White, J. D., \& Truly, E. L. (1989), Price-Quality integration in warranty evaluation-a preliminary test of alternative models of risks assessment. Journal of Business Research, 19(20), 109-125.

Yujie, W. (2008). Does Consumer ethnocentrism affect Purchase intentions of Chinese Consumers? Mediating effect of Brand Sensitivity and moderating Effect of Product Cues. Journal of Asia Business Studies, 3(1), 54-66. 